\title{
The left foot aryballos wearing a network sandal
}

Book or Report Section

Accepted Version

Smith, A. (2018) The left foot aryballos wearing a network sandal. In: Pickup, S. and Waite, S. (eds.) Shoes, slippers and sandals. Feet and footwear in Classical antiquity. Routledge, Abingdon, Oxfordshire, pp. 195-215. ISBN 9781472488763 Available at http://centaur.reading.ac.uk/79750/

It is advisable to refer to the publisher's version if you intend to cite from the work. See Guidance on citing.

Published version at: https://www.routledge.com/Shoes-Slippers-and-Sandals-Feet-and-Footwear-in-ClassicalAntiquity/Pickup-Waite/p/book/9781472488763

Publisher: Routledge

All outputs in CentAUR are protected by Intellectual Property Rights law, including copyright law. Copyright and IPR is retained by the creators or other copyright holders. Terms and conditions for use of this material are defined in the End User Agreement. 


\section{www.reading.ac.uk/centaur}

\section{CentAUR}

Central Archive at the University of Reading

Reading's research outputs online 


\section{Chapter 9. The Left Foot Aryballos Wearing a Network Sandal}

Amy C. Smith

Among the ancient Greek vases in the shape of sculptural forms - human, animal or otherwise (thus 'figure vases') - foot vases are best suited to their erstwhile contents, namely perfumed oils. Such oils could have been used on removal of sandals or slippers, for example, in bathing, sympotic, erotic and funerary settings. Foot vases thus might be found in many archaeological contexts: athletic, household, sanctuary or mortuary. With or without known archaeological contexts, however, they evoke transition and the interaction of humans and the senses - especially scent - with their environment. As Reynold Higgins (1959, v) noted, 'they are frequently ignored by students both of vases and of terracottas' and I welcome this opportunity to bring this typological study to the consideration of a broader audience.

\section{[Insert fig. 9.1 here - landscape]}

Figure 9.1 Archaic aryballos in the shape of a sandaled left foot, 550-525 BC.

Reading, Ure Museum 69.7.1.

\footnotetext{
- I am grateful to Sadie Pickup and Sally Waite for their invitation to publish this article and for their patience and care. I am grateful to the following individuals for their assistance with my study of relevant museum objects: Christina Avronidaki and Maria Chidiroglou (Athens, National Archaeological Museum); Kordelia Knoll and Saskia Wetzig (Dresden, Staatliche Kunstsammlungen); Martin Boss (Erlangen, Antikensammlung); Benjamin Harridge and Alex Truscott (London, British Museum); Marianne Bergeron, John Boardman, Michael Vickers, Mark Norman, Alison Roberts (Oxford, Ashmolean); Alexandra Kardianou-Michel (Paris, Louvre); Jayne Holly-Wait (Reading, Ure); Georg Plattner (Vienna, Kunsthistorischesmuseum). I am also grateful to Lucilla Burn, Jean-Paul Descoeudres and Sonya Klinger for comments on earlier drafts of this article.
} 
This chapter considers a particular type of foot vase, the archaic foot aryballos clad in a network sandal, an unprovenanced example of which is displayed at the Ure Museum of Greek Archaeology at the University of Reading (Figure 9.1). ${ }^{1}$ Traditional scholarship dates it to the third quarter of the sixth century BC and suggests that this aryballos - like most foot vases and indeed many plastic vases - was made in East Greece (Ducat 1966, 182-84; Dohan Morrow 1985, 6-9). ${ }^{2}$ While the archaeological evidence supports this date it does not support the supposed place of manufacture. There are at least 32 such vessels known to me, 22 of which Jean Ducat catalogued as his type B - aryballoi representing left feet wearing a network sandal - while Katherine Dohan Morrow later absorbed them into her group II. In Table 1 I amalgamate, reduce and expand on their lists, for which I include cross-references. ${ }^{3}$

\footnotetext{
${ }^{1}$ Reading, Ure Museum 69.7.1. Annie D. Ure purchased this foot aryballos at Sotheby's in London, 1 July 1969 (lot 85) but it has thus far eluded the literature unless, perhaps, it is Ducat (1966, B16 or B22); Dohan Morrow (1985, II.13 or II.22). The former (from Boeotia) is listed by Ducat (1966, 183), as on the market in Athens, while Dietrich von Bothmer had informed Ducat that the latter, ex Brommer P521, was 'on the market in New York'. I have guessed that the latter is more likely and this is reflected in Table 1.

${ }^{2}$ Higgins (1959, 33 no. 1656) lists many comparanda for London, British Museum 1928,1117,49. Trumpf-Lyritzaki (1969) catalogues vases from a later period.

${ }^{3}$ I have omitted several from Dohan Morrow’s list: Athens, National Museum 9731, Dohan Morrow’s II.24, seems to be a repeat of her II.21 (not otherwise noted by Karousou 1987). Athens, nAM 2012, Dohan Morrow’s II.28 (and Nicole 1911, 143 no. 812) and 9731 (Nicole 1911, 143 no. 816) are not foot aryballoi (perhaps Nicole got the numbers wrong). Bonn 36, Dohan Morrow's II.1, is of a different type. Munich A 1080, Dohan Morrow's II.29, is the Arndt inventory number formerly applied to the pair of aryballoi in Munich, now with inventory numbers 6640 and 6641. Erlangen I 621, which Higgins mentioned $(1957,134)$, turns out to be a different (Hellenistic) form. I have added excavated examples from Archontiko (now in the Pella Museum), Eretria and Tocra, as well as one in Oxford,
} 
Through a thorough re-evaluation of the fabric and findspots of this type of foot aryballos I offer a solution to the long-standing 'enigma' of its place of origin. ${ }^{4} \mathrm{~A}$ reconsideration of the findspots of these vases also encourages a deeper understanding of the function and meaning of these aryballoi and the sandals with which they are decorated.

\section{[Insert fig. 9.2 here - landscape]}

Figure 9.2 Back view of an archaic aryballos in the shape of a sandalled left foot, showing the heel, ankle, strap and backplate. Reading, Ure Museum 69.7.1

This type of foot aryballos is relatively tall (the Ure example measures $8.2 \mathrm{~cm}$ in height) because it includes a full ankle. Its ankle gives prominence to the narrow neck and broad mouth of the aryballos of which it is part; a short vertical strap handle joins the mouth to the back of the ankle, where there is a square plaque or backplate. Added white dots embellish the radiating black and red tongues on the upper surface of the mouth and an egg-and-dot frieze at the top of the ankle. A black zigzag decorates the vertical surface of the rim. This is perhaps the only area where we find variation across the type. Ours is one of eight decorated here with zigzags. Seven have oblique lines while five have lines of chevrons, in both cases stacked vertically. The backplate is decorated with an incised palmette, painted with white dots on black and red leaves (Figure 9.2). Ours is one of 18 decorated on the backplate with this palmette. An example in Warsaw is said to have a gorgoneion on the backplate, yet it

Ashmolean Museum AN1954.12. Boardman and Hayes (1966,153 n. 3) also note a parallel from Chios (Phanai) that seemingly remains unpublished and I have not had a chance to visit it.

${ }^{4}$ Ducat (1966) put them at the end of his book in the 'Enigmes' section, 181-85. 
is not clear in the published illustration. ${ }^{5}$ When this vase was in Königsberg (until 1948), moreover, Reinhard Lullies reported that the backplate was decorated with a bird (Lullies 1935, 42 no. 94). ${ }^{6}$ If it is indeed a gorgoneion on the backplate, however, it is but one of many decorative elements that connects our type with the foot aryballos that wears a simpler yoke sandal, Ducat's type A or Dohan Morrow's group I (Figure 9.3 left. Ducat 1966, 181-82; Dohan Morrow 1985, 3-6). Dohan Morrow notes the fundamental ways in which these two foot aryballoi differ. Besides the form of the sandal there are differences in the characteristics of the foot (Dohan Morrow 1985, 8). The type A feet are a larger. Although she suggests they are 'less elegant' I would contend that they are rather broader, perhaps closer to human proportions or even more masculine.

\section{[Insert Figure 9.3 here - landscape]}

Figure 9.3 Archaic foot aryballoi of Ducat's types A and B (Dohan Morrow's type I and II), London, British Museum 1854,0810.5 (said to be from Samos) and $1928,0117.49$.

Our foot aryballos, like all of its siblings, is further enhanced with painted white toenails. One of the British Museum's aryballoi has the best preserved white toenails (Figure 9.3, right). ${ }^{7}$ The main decorative element is, however, the sandal with which the foot is clad, effected in relief decoration, painted purplish-red, that gives the effect of a network of straps that encase the heel and toes. From the nets emerge loops

\footnotetext{
${ }^{5}$ Warsaw, National Museum 199233 (CVA Warsaw 2, 21, pl. 43.6).

${ }^{6}$ I cannot determine the decoration on the backplate for the others either because of their state of preservation or because of a dearth of appropriate photographs.

${ }^{7}$ London, British Museum 1928,0117.49
} 
gathered by a single lace at the instep; the ends of this lace rise to the top of the ankle where it is finally tied in a bow. This network sandal is supported by a thick sole or krepis that lends itself to the name for this type of shoe (predecessor to the Roman soleae), which is transitional between the plain sandal and the high-stepped shoe (Higgins 1959, 34). Each aryballos has two rows of black dots on the edge of the sole. ${ }^{8}$ The dots probably represent stitches, one row attaching the sandal itself to the sole and a second row attaching an upper sole to a lower sole. This double sole certainly suggests a well made and potentially expensive shoe.

\section{[Insert Figure 9.4 here - landscape]}

Figure 9.4 Map of the Mediterranean indicating findspots of Ducat's type B networksandalled foot aryballoi. Key: circle $=1$ find; square $=2$ finds; triangle $=3$ finds.

\section{Findspots}

The supposed East Greek origins of these foot aryballoi have persisted because of flawed methodology, whereby stylistic assignations of the vases have been incorrectly recorded as 'findspots'. In charting the actual findspots of Ducat's type B foot aryballos (Figure 9.4) I have stripped away these false findspots and reluctantly left the purported findspots of the Oxford, Vienna and New York vases. ${ }^{9}$ Of these, the only one that is perhaps reliable is the Eretrian findspot of the Vienna aryballos, reported by Geladakis, who indeed passed on many vases with Boeotian and Eretrian

\footnotetext{
${ }^{8}$ None of the examples I have viewed in person (in Eretria, London, Oxford, Pella, Reading and Vienna) have the white sole that Dohan Morrow ascribes to the entire group $(1985,8)$, nor do published photographs of the others suggest such a detail.

${ }^{9}$ New York, Metropolitan Museum 41.162.195.
} 
findspots. ${ }^{10}$ Of the 32 known examples, 21 have provenances. 11 were found on the mainland, including Aigina (1), Archontiko in Macedonia (2), Boeotia (2), Corinth (possibly 1), Eretria on Euboea (3), Olympia (1) and Perachora (1). Two others are said to have been found in Greece. While there was clearly a broad geographic spread, from as far west as Taranto and Tocra (now in Libya) to as far east as Olbia (on the Black Sea), the mainland provenances predominate and Eretria and its near neighbour Boeotia stand out as the primary destinations for these vases. Remarkably none have been found in Athens.

\section{Date}

The dating of this type of foot aryballos to the third quarter of the sixth century on the basis of stylistic criteria has stood the test of time and been supported by recorded finds in published excavations. Higgins compared the palmettes on some of its backplates to those on Attic little master cups also from the third quarter of the sixth century (Higgins 1959, 33). One of our aryballoi was found in a grave (no. 2) at Taranto that was dated to $550 \mathrm{BC}$ on the basis of other vases found with it (Lo Porto 1962, 157-58 no. 7, fig. 9). More recently, excavators in Macedonia have given the Archontiko tombs containing this type of foot aryballos, T280 and T283, dates of 550 and 530, respectively, on the basis of their Attic ceramic finds (Crysostomou and Crysostomou 2012, 493-95). The example found under the North wall of the Stadium at Olympia likewise was associated with ceramic material from the middle of the $6^{\text {th }}$ century (Kunze 1963, 105-13). Our aryballos, Ducat's type B, is roughly

\footnotetext{
${ }^{10}$ The Oxford example has two purported findspots, Corinth and Taranto, neither of which is evidenced. It is possible that the New York aryballos was reported to be from Olbia as it was paired in the Chmielowski collection with a Hellenistic slipper lekythos that was also found at Olbia.
} 
contemporary with or perhaps slightly later than his type A, a slightly larger left foot wearing a yoke sandal, made into an aryballos with the addition of a similar neck and mouth. Ducat notes that the form of the foot of type A corresponds to Richter's (1966, 182) Tenea-Volomandra group, 575-550.The only well dated example of this earlier type found in a controlled excavation was found Morgantina, 69-132, in a grave Necropolis II, tomb 9, burial 9 - likewise dated close to $550 \mathrm{BC}$ on the basis of its inclusion of a figurine of a Siren (Bell 1981, 16, 130 nos. 51 (Siren) and 53 (Aryballos), pl. 12). ${ }^{11}$

\section{Workshop}

Otto Rubensohn (1962) was perhaps the first to note that - on the basis of colour, size and form - these aryballoi must come from the same workshop. I am persuaded by Semni Karousou's $(1987,56)$ observation, moreover, that the five such vases in Athens were made in the same mould, perhaps by the same artist. ${ }^{12}$ While Karousou maintained their traditional Ionian origin, Rubensohn proposed a Boeotian workshop, on comparison with Gryton's foot aryballos in Boston (Fairbanks 1928, 183-84 no. 536, pl. 51). ${ }^{13}$ Despite the different form and overall treatment of this aryballos, its fabric is indeed similar to that of ours.

Jean Ducat (1966, 184), suggested, moreover, that his type B and a related type A - aryballoi representing left feet wearing a yoke sandal - were created in the same workshop. What unifies Ducat's groups A \& B is the shape of mouth, neck and

\footnotetext{
${ }^{11}$ Lindos 1928 (now in Istanbul) and Eléonte 1131 (ELE 597-S) (now in the Louvre) were also found in tombs.

${ }^{12}$ Athens, National Museum 2050, 2063, 2079, 9734 and 16517.

${ }^{13}$ Boston, Museum of Fine Arts 98.897. See also Raubitschek and Raubitschek (1966, 155-56), for a catalogue of Gryton's works and other signed pottery from Boeotia.
} 
backplate, as well as the treatment of the mouth (with tongues), top of ankle (with egg-and-dot frieze) and backplate (some of both types are decorated with palmettes). Jan Six $(1885,182)$ gave type A a Corinthian origin on account of the gorgoneion on some of its backplates, although he thought the British Museum aryballos (Figure 9.3, left) 'of too good workmanship and finish to be as early as the Corinthian vases are generally thought to be'. ${ }^{14}$ Yet Sonia Klinger has now suggested that these type A vases may have inspired Corinthian foot models found in the Sanctuary of Demeter at Corinth. ${ }^{15}$ The first rather than second or third quarter of the sixth century, moreover, was the heyday of Corinthian plastic vases (Payne, 1931, 176-80; Robertson 1938, 48). From my own observation of the colour of its fabric and its use of shiny black glaze, I would suggest that Ducat's type A is Attic or Boeotian. Then we might consider that our network-sandalled foot aryballos, Ducat's type B, was a local adaption of this Attic or Atticising type, for which a deeper investigation of the fabric and style of decoration of our aryballos is in order.

\section{Fabrics}

Scholars have long hesitated on assigning our network-sandalled foot aryballos, Ducat's type B, to East Greece because of its fabric, a slightly micaceous, finegrained yellowish-red clay, just a shade yellower than Attic. The colour of the fabric of those that I have studied first-hand ranges from 7.5YR 6/6-5/6, which is roughly in line with Jean-Paul Descoeudres' reading of 7.5YR 6.5/4 for the Basel

\footnotetext{
${ }^{14}$ Payne $(1931,79-87)$ argued that the gorgoneion motif originally came from Corinth. On this matter see, more recently, Tsiafakis $(2003,85)$.

${ }^{15}$ Klinger forthcoming.
} 
example. ${ }^{16}$ Adolf Furtwängler $(1887$, text to pl. 52, and 1885,1004$)$ tentatively suggested it was Attic, in fact, in his discussions of the example in Berlin, ${ }^{17}$ as did John Boardman (1966, 153 and n. 5) regarding the example he found in Tocra, whereupon he dismissed Rubensohn's $(1962,128)$, suggestion that it was a Boeotian type. Higgins $(1959,34)$ rightly noted that Rhodes was an unlikely home for these aryballoi, whose mouths are dissimilar to those of Rhodian aryballoi and glaze is too black and shiny, so he hesitantly suggested they were made by the 'Aphrodite type' potters in Samos or Miletos (Higgins 1967, 37). M.I. Maximova (1927, 93), catalogued only type A, which she took to be from Samos. Malcolm Bell $(1981,16)$ notes that both types, however, are decorated with black glaze and applied colors, unlike the members of the Aphrodite Group, which received only applied matt colors. Felice Lo Porto $(1962,157)$ also suggested Samos, as none had been found in Rhodes. While one of Ducat's type A, however, was found at Lindos on Rhodes (Blinkenberg 1931, 473-74 no. 1928, pl. 85), neither has been found at Samos. Emil Kunze and Descoeudres likewise stuck with an East Greek origin (Kunze 1963, 112; CVA Basel 1,64, pl. 150). ${ }^{18}$

In the 1960s-1980s Boardman, Descoeudres and others tried to use scientific analyses to distinguish between Attic, Euboean and other fabrics (Boardman and Schweitzer 1973; Descoeudres and Stern 1977; Boardman and Jones 1987) and indeed two of our aryballoi were tested. My efforts to unearth the precise results for the Reading aryballos (Figure 9.1) have failed and - despite a tell-tale hole in the base

\footnotetext{
${ }^{16}$ Basel, Antikenmuseum Z-321 (CVA Basel 1, 64, pl. 19.15.).

${ }^{17}$ Berlin, Antikensammlung F 3956 (2886).

${ }^{18}$ Prof. Descoeudres (personal communication 21.12.2016) has now noted that this was an error.
} 
of the Oxford aryballos, any analyses of it remains unrecorded and unpublished. ${ }^{19}$ Through petrographic analyses, however, Boardman linked the former to three artefacts (Boardman and Jones 1986, 673): a Daedalic figurine 'which is surely East Greek' ${ }^{20}$; a 'Rhodian' hedgehog vase excavated at Kamiros in $1859^{21}$; and a fragmentary alabastron broken in two parts, whose top is in the form of a female bust. $^{22}$ The latter two are roughly contemporary, dated to c. 520 BC. Yet none of these comparanda are of certain origin and only one has a secure findspot. This inconclusive result nonetheless encouraged Boardman to dismiss his Attic origin for our aryballoi and thus the matter was 'put to bed' for several decades. Boardman's petrographic analysis of some vases in the Louvre, in collaboration with Angelika Waiblinger, meanwhile resulted in 'little uniformity' in the Boeotian 'control' sample, 'which may be indicative of the clays of the area' (CVA Louvre 17 [1974] appendix 3). That is, above and beyond the problem that Boeotian potters shared clay pits with Attic potters (Aloupi-Siotis 2008), Boeotian potters also had at their disposal the huge area of clay deposition around Euboea, which also shares characteristics with Attika and whose rare earth elements are difficult to analyse statistically. ${ }^{23}$

\section{[Insert fig. 9.5 here - landscape]}

Figure 9.5 Atticising black-figure Euboean (?) lekanis, excavated from Kamiros tomb F73. London, British Museum 1864,1007.1569.

\footnotetext{
${ }^{19}$ Oxford, Ashmolean AN1954.12. Vickers (1999, 17).

${ }^{20}$ Oxford, Ashmolean, 1948.311.

${ }^{21}$ London, British Museum 60.4-4.34. Higgins (1959, 26 no. 1641).

${ }^{22}$ London, British Museum 88.6-1.752[2]. Higgins (1959, 23 no. 1630).

${ }^{23}$ I am grateful to Helen Hatcher (personal communication 29.11.2016) for her thoughts on this matter.
} 


\section{Style}

The decorative style, a sum of the motifs and techniques employed in decorating the aryballos, suggests a central rather than East Greek origin for our network-sandalled foot aryballos. As noted above, the black glaze and applied colours are closer to Attic than to East Greek. The treatment of the mouth - thick and broad, with a flat upper surface and decorated with tongues - is Corinthian or Corinthianising, as may be the palmette and also the gorgoneion which, as noted above, is more characteristic of the yoke-sandalled aryballos. Especially in the second half of the sixth century, however, Boeotian and perhaps Euboean potters not only shared clays but also borrowed decorative techniques and tendencies from Attic and Corinthian potters. John Boardman (1952) brought attention to some purported 'Attic' vases found in Eretria that might have been local wares. ${ }^{24}$ The vertically-stacked chevrons on some of our type $\mathrm{B}$ rims recall a motif that characterises a class of lekanides (for example, Figure 9.5), earlier identified as Chalcidian (Boardman 1952, $42-43$ B.F. 16, pl. 13). ${ }^{25}$

Despite his initial comments, however, Boardman concludes that 'The close Chalcidian parallels to the lekanis fragment are interesting but not significant' (Boardman 1952, 44). Tongues similar to those on our aryballoi are also found at the top of the foot and above the palmettes on the top of the body the Herakles amphora, which is dated to c. $550 \mathrm{BC} .^{26}$ The palmettes on that amphora also recall those on the backplates of eight of our type B aryballoi. The double dot band on the sole of the

\footnotetext{
${ }^{24}$ See, for an earlier period, Lemos and Hatcher (1991).

${ }^{25}$ Würzburg, Martin von Wagner Museum 163. Langlotz (1932, pl. 120) from Arezzo; Cologne (from Italy); Copenhagen (CVA Copenhagen 3, pl. 100.3, from Nola); Athens, Akropolis 485. Graef and Langlotz (1925, pl. 25); London, British Museum 1864,1007.1569, excavated from Kamiros tomb F73. See also Kraiker (1934, 144 n. 2).

${ }^{26}$ Athens, National Museum 12075 (Nicole 1911, 167 no. 889, pl. 8).
} 
sandal recalls the dot band customarily used by Attic amphora painters and related lekythos painters: the Leagros Group, Michigan and Edinburgh Painters (last quarter of the sixth century) and later Bompas Group and Dot Band Class (first quarter of the fifth century). In Eretria Boardman found this motif on a fragment from a whiteground lekythos showing Herakles fighting Geryon, possibly related to the Edinburgh Painter (Boardman 1952, 42 B.F. 12, pl. 14). ${ }^{27}$ In her handwritten notes in the archives of the Ure Museum, ${ }^{28}$ Ure suggested that the dots between tongues matched those on a Euboean skyphos in New York, attributed to the Dolphin Group. ${ }^{29}$ Her Euboean assignation for Beazley's Dolphin Group was confirmed by trace element analysis, although 'the clays look like Attic' (Boardman and Schweizer 1973, 27677).

\section{[Insert fig. 9.6 here - portrait]}

Figure 9.6 Display of the artefacts found in Archontiko, Western cemetery T283 (c. 530 BC) in the Pella Museum. Photograph: A. C. Smith.

\footnotetext{
${ }^{27}$ Higgins $(1959,33)$ connects these with the fingernails on a fragment of a figure vase from Al Mina, MN 110 (now Oxford, Ashmolean Museum and illustrated in Woolley 1938, 169, pl. X), suggesting that they are of the same fabric.

${ }^{28}$ Ure Museum Archives D3. Late in my research Jayne Holly-Wait uncovered in the Ure Museum archives (D31/1 and D31/3) two envelopes filled with Annie D. Ure's notes, handwritten in pencil in the 1950 s, mostly on $1 / 4$-page reused paper - more than a decade before she purchased the Ure foot lekythos on which this article is based - while researching the fourth to third century BC 'Olbian' lekythos type represented in the Ure Museum (45.9.2) and another one found by her husband, Percy N. Ure, at Rhitsona (Grave 57 no. 3: Ure 1913, 43, pl. xi.3).

${ }^{29}$ New York, Metropolitan Museum 24.97.94: von Bothmer (1969, 42, fig. 31) notes that this 'Corinthian style skyphos' (thus kotyle) was once considered Corinthian and then Attic ( $A B V 458.27)$.
} 


\section{Archaeological Contexts}

As I noted in my introduction, foot vases might seem appropriate in many archaeological contexts- - athletic, household, sanctuary or mortuary - yet the majority of our network-sandalled foot aryballoi with recorded findspots - five or six of them - come from graves. I have noted the finds from Taranto and Archontiko above, although it is worth emphasising that the latter two emerged from two of four richest of the archaic heroic warrior graves in the Western cemetery at Archontiko, T280 and T283 (Figure 9.6. Crysostomou and Crysostomou 2012, 493-95). Two of the examples now in Athens ${ }^{30}$ are said to have been found in tombs in Boeotia (Karousou 1987, 56), and another in Eretria was discovered in a tomb - one of a triplet of cist graves discovered during works to lay a water pipe (Andreiomenou 1960, 153). ${ }^{31}$ The discovery of such a foot aryballos at Olympia was taken as remarkable at the time because of the rarity of Eastern Greek products at the site (Kunze 1963, 112). It is now remarkable, however, insofar as it is the only recorded find of such a vase in an athletic context, although it shares a votive context with Perachora, Paros and perhaps Chios. $^{32}$

The predominant mortuary context of these foot vases recalls the placement of ceramic boots, not necessarily vessels, in earlier tombs in Attika (Dohan Morrow 1985, 3 n. 1), some as singletons - in late Mycenaean tombs at Haliki and Pikermi and others in pairs, in early geometric tombs - of a man, Isodos, at Eleusis, of a youth on St. Demetrios Street in Athens and of a woman near the Areopagos. Yet the latter

\footnotetext{
${ }^{30}$ Athens, National Museum 2063 and 9734.

${ }^{31}$ Eretria ME 1251. Sapouna Sakellaraki 1995, 80, fig. 60.

${ }^{32}$ Boardman and Hayes noted that there was one at Phanai $(1966,153$ n. 3) although I have not yet found any publication of this vase. I thank Lesley Beaumont for her kindness in looking (alas in vain) for this vessel on her latest visit to Phanai.
} 
group are all found in pairs while all of our type A and B aryballoi found in excavation contexts were singletons. All of ours represent single left feet, moreover, so one must then ask why feet and, further, why left feet?

Through an investigation of the meaning of foot vases in tombs, Carina Weiss (1966) compared these vessels with amulets and other items bearing images of feet. She suggested that these images might recall special events in the lives of men and perhaps even women and - especially in the case of the ornate network sandals with high soles - might suggest some sort of social status. The rich Archontiko finds certainly encourage this latter suggestion. In the case of women these two elements are crystallised in the celebration of marriage, an event during which attention was brought in particular to the nymphides or slippers worn by the bride (Smith 2011, 85). As always with marriage in antiquity, there is a close connection to death, which again brings us back to the sepulchral destination of many such vessels. There is no evidence from the finds of these aryballoi, however, to connect them with brides or even women, however, and on the contrary the placement in rich male burials at Archontiko would encourage a masculine rather than feminine gender assignation. My earlier suggestion that the type A aryballoi might reflect a more masculine foot, as compared to the smaller and slimmer type B aryballoi, however, should not have any influence on our expectations of whether the vessels would have been used by or given to either women or men. One of those two Archontiko graves, in fact, contained several female-headed alabastra (Figure 9.5)

As I suggested in the introduction, however, footwear, whether sandals, slippers, or shoes, is relevant to transition. One would take them off perhaps on entering a home and certainly for bathing, either with water or scraping. In either case oil, unguents and ointments contained within would be useful. One should not 
overlook, moreover, the healing properties of oil and of course the sepulchral uses of oil, especially of the perfumed variety. ${ }^{33}$ So the contents are likely relevant to funerary cult. The symbolism of transition in the sepulchral realm also recalls monosandalic Jason, which might help us to address the issue of the single foot. ${ }^{34}$

The single foot and/or its sandal seem to have earned some significance in history, myth and philosophy, therefore art. Despite his preference for practical explanation over mythic, Thucydides knew of a religious or superstitious reason for the Plataian escapees to go with a single sandal (3.22.2. Edmunds 1984). Myth is replete with monosandalic heroes and gods. Jason fulfilled a prophecy that a onesandaled man would usurp the throne of Pelias, for which reason he was sent abroad to fetch the golden ram (Fowler 2013, 205-208). He is represented by his sandal on the reverse of some coins from Larisa (Neils 1990, 630 no. 1). ${ }^{35}$ Monosandalic Jason is popular in Roman painting and funerary urns/sarcophagi (Neils 1990, 631, 635 and 638). Is this connection to the funerary realm coincidental or is his monosandalism an evocation of transition, even freedom (Deonna 1935, 58 and 66)? The transitional essence of the monosandalic persona is epitomised in Artemidoros' story of a man urged to sacrifice to Hermes, the 'one-sandalled one' (monokrepis), which state resulted from his giving one of his shoes to Perseus (Oneirokritika 4.63). Yet Jason's single sandal seems to be on his right foot, at least on a Pompeian painting in the House of the Golden Cupids, room G (VI.16.7).

\footnotetext{
${ }^{33}$ I am grateful to Katerina Volioti for sharing with me her thoughts about the healing properties of oil (personal communication, 28.11.2016).

${ }^{34}$ For broader discussions of monosandalism see chapters 10 and 12 in this volume.

${ }^{35}$ It is Apollonionos Rhodios 1.10-11, however, who explains that, on crossing the River Anauros, Jason rescued one of his sandals from the mud but left the other behind.
} 
Why then do both our type A and B foot aryballoi represent left feet? It appears statistically unlikely that right foot aryballoi of these types also existed but none have been found, so we should assume that the mouldmakers planned for their lot of foot aryballoi to represent left feet. Homeric prejudice would suggest that the left would be an unlucky choice (see, for example, Hom. Il. 24.315-321 and Od. 2.146-154). By the fifth century, one of the words for left, even comes to mean 'ill-omened' (Soph. Aj. 1225) or 'awkward' (Aristoph. Vesp. 1265) as contrasted to the 'right' or 'righthanded', which comes to mean 'clever' (Aristoph. Neph. 417). The inclusion of these aryballoi in heroic graves would suggest they were not used for the ill-omened or to symbolise bad luck. According to Aristotle, who also lived later than our aryballoi, however, the right side initiated movement, with the contrary result that a man would step forward first with his left foot and/or carry the burden on his left side. Might left then be construed as symbolic of movement, as was the interpretation of monosandalism noted above? A more plausible explanation is that the left reflected the feminine, as found in the Hippocratic treatises (Lloyd 1962, 60), which is a characteristic that might not be unwelcome in the tomb of a masculine hero, to provide the healing and restoring qualities of oil.

Thoughts on use of foot aryballoi in tombs as status markers, symbolic of transition and important for the oil that they contained, remain speculative given the relative dearth of archaeological contexts. Yet I hope to have shown that the findspots, fabric and style of decoration of these vessels all suggest a central Greek locus, probably on Euboea, for the workshop and perhaps single craftsman who created them so consistently that it seems one of our earliest examples of mass 
production of fine wares. ${ }^{36}$ While Karousou (1987) suggested that the type A vases were Boeotian copies of the Ionian type B vases, I would suggest rather that the type B foot aryballos was a Euboean adaptation of an Attic or Boeotian type A foot aryballos. ${ }^{37}$ As noted by Annie Ure, 'The close resemblance between Attic and Eretrian vase-painting makes it difficult to distinguish Atticising work made in Eretria from Attic imports, while so far black-figured vases of the archaic period from workshops in Chalcis have not been recognised' (Ure 1962, 138). More than half a century later the situation hasn't changed and perhaps a reassignation of this aryballos will be a useful step towards an identification of late archaic Euboean workshops.

\section{Bibliography:}

1899. 'Erwerbungen des Museum of Fine Arts in Boston im Jahre 1898' in Archäologischer Anzeiger, 135-46

Andreiomenou, A.K., 1960. 'Euboia', in Archaiologikon Deltion 16, 149-53

Aloupi-Siotis, E., 2008. 'Recovery and Revival of Attic Vase-Decoration Techniques: What Can They Offer Archaeological Research?’ in K. Lapatin ed., Special Techniques in Athenian Vases. Proceedings of a symposium held in connection with the exhibition The Colors of Clay: Special Techniques in Athenian Vases, at the Getty Villa, June 15-17, 2006 (Los Angeles: J. Paul Getty Trust) 113-28

Bell, Malcolm, 1981. Morgantina Studies I. The Terracottas (Princeton: Princeton University Press)

\footnotetext{
${ }^{36}$ For the relative lack of evidence for mass production in Attic and related fine wares see Smith 2014, $134-35$.

${ }^{37}$ The glaze wash on the type A is a Boeotian characteristic (Boardman 1952, 44).
} 
Blinkenberg, C., 1931. Lindos. Fouilles de l'Acropole 1902-1914 I (Berlin: de Gruyter)

Blundell, Sue, 2011. 'Beneath their shining feet: shoes and sandals in Classical Greece', in Giorgio Riello \& Peter McNeil, eds, Shoes. A history from sandals to sneakers (London: Bloomsbury) 30-49

Boardman, J., 1952. 'Pottery from Eretria', in Annals of the British School of Archaeology 47, 1-48

Boardman, J. and J. Hayes, 1966. Excavations at Tocra 1963-1965. The Archaic Deposits I. BSA Supplement 4 (London: Thames and Hudson)

Boardman, J. and R.E. Jones, 1986. 'Provenance Studies of Greek Pottery of the Historic Period' in Greek and Cypriot Pottery. A Review of Scientific Studies. Fitch Laboratory Occasional Paper I (Athens: British School at Athens) 627-747.

Boardman, J. and F. Schweizer, 1973. 'Clay Analyses of Archaic Greek Pottery' in Annual of the British School at Athens 68, 267-83

Bothmer, D. von, 1969. 'Euboean Black-figure in New York', in Metropolitan Museum Journal 2, 27-44

Crysostomou, A. and P., 2012. 'The "Gold-wearing" Archaic Macedonians from the Western Cemetery of Archontiko, Pella' in Michael Tiversios, Pantelis Nigdelis and Polyxeni Adam-Veleni eds, Threpteria. Studies on Ancient Macedonia (Thessaloniki: Auth Press) 490-518

Deonna, W., 1935. 'Момокри́ $\pi \_\varepsilon \varsigma '$, in Revue de l'histoire des religions 112, 50-72

Descoeudres, J.-P. and W.B. Stern, 1977. 'X-ray Fluorescence Analysis of Archaic Greek Pottery' in Archaeometry 19, 73-86

Ducat, J., 1966. Les vases plastiques Rhodiens archaïques en terre cuite (Paris: Boccard) 
Dohan Morrow, K., 1985. Greek footwear and the dating of sculpture (Madison, Wisc.: University of Wisconsin Press)

Edmunds, L., 1984. 'Thucydides on Monosandalism' in Studies Presented to Sterling Dow. GRBS Monograph 10, 71-75.

Fairbanks, A., 1928. Catalogue of Greek and Etruscan Vases I (Cambridge, Mass.: Harvard University Press)

Fowler, R.L.H., 2013. Early Greek Mythography 2 (Oxford: Oxford University Press)

Furtwängler, A., 1885. Königliche Museen zu Berlin. Beschreibung der Vasensammlung im Antiquarium II (Berlin: W. Spemann)

Furtwängler, A., 1887. La collection Sabouroff: Monuments de l'art grec (Berlin: A. Asher \& Co.)

Graef, B., Ernst L. et al. 1925. Die antiken vasen von der Akropolis zu Athen (Berlin: Gruyter) I

Greifenhagen, Adolf. 1936. 'Ausserattische Schwarzfigurige Vasen im Akademischen Kunstmuseum zu Bonn', in Archäologischer Anzeiger, 343-406.

Herrmann, P., 1898. 'Erwerbungen der Antikensammlungen in Deutschland 1896' in Archäologischer Anzeiger, 129-39

Higgins, R.A., 1959. Catalogue of the Terracottas in the Department of Greek and Roman Antiquities, British Museum II (London: British Museum)

Higgins, R.A., 1967. Greek Terracottas (London: Methuen)

Karousou, S., 1978/1980 [1987]. ‘Ionismes Béotiens', in Anadolu 21, 55-62

Klinger, S., forthcoming, 'Terracotta Models of Sandaled Feet. Votives from the Sanctuary of Demeter and Kore on Acrocorinth', in Hesperia, $\mathrm{xxx}$

Kraiker, W., 1934. 'Review of The Origin of Chalcidian Ware' in Gnomon 10, 24145 
Kunze, E., 1963, 'Die Ausgrabungen in Olympia. Laufbahn und Nordwall des Stadions, 1958-1961', in Archaiologikon Deltion 17.2 (1961/62) 107-24

Langlotz, E., 1932. Griechische Vasen in Würzburg (Munich: J.B. Obernetter)

Lemos, I.S. and H. Hatcher, 1991. 'Early Greek Vases in Cyprus: Euboean and Attic' in Oxford Journal of Archaeology 10, 197-208

Lloyd, G.E.R., 1962. 'Right and Left in Greek Philosophy', in Journal of Hellenic Studies 82, 56-66

Lo Porto, F.G., 1962. 'Tombe Arcaiche Tarentine con Terrecotte Ioniche' in Bollettino d'Arte 35, 153-70

Lullies, R., 1935. Antike Kleinkunst in Königsberg Pr. (Königsberg: Gräfe und Unzer) Maximova, M.I., 1927. Les vases Plastiques dans l'Antiquité, trans. Michel Carsow (Paris: Paul Geuthner)

Neils, J., 1990. 'Iason' in LIMC 5, 629-38

Nicole, G., 1911. Catalogue des vases peints du Musée national d'Athènes. Supplément (Paris: A. Fontemoing)

Payne, H., 1931. Necrocorinthia (Oxford: Clarendon Press)

Payne, H., 1940 Perachora. The Sanctuaries of Hera Akraia and Limenia (Oxford: Clarendon Press)

Raubitschek, A.E. and I.K., 1966. 'Early Boeotian Potters' in Hesperia 35, 154-65.

Richter, G.M.A., 1953. Handbook of the Greek Collection (Cambridge, Mass.: Harvard University Press)

Robertson, C.M., 1938. 'A Group of Plastic Vases' in Journal of Hellenic Studies 58, $41-50$.

Rubensohn, O., 1962. Das Delion von Paros (Wiesbaden: F. Steiner Verlag) 
Sapouna Sakellaraki, E., 1995. Eretria, Site and Museum (Athens: Archaeological Receipts Fund)

Sieveking, J., 1930. Bronzen, Terrakotten, Vasen der Sammlung Loeb (Munich: A. Buchholz)

Six, J., 1885. 'Some Archaic Gorgons in the British Museum' in Journal of Hellenic Studies 6, 275-86

Smith, A.C., 2011. 'Marriage in the Greek World', in Thesaurus Cultus et Rituum Antiquorum 6 (Malibu: J. Paul Getty Trust) 83-94

Smith, A.C., 2014. 'Variation among Attic fine wares: The case of the Pan Painter's pelikai', in A. Kotsonas, ed., Understanding standardization and variation in Mediterranean ceramics: mid 2nd to late 1st millennium BC. BABesch Suppl. 25 (2014) 133-48.

Trumpf-Lyritzaki, M., 1969. Griechische Figurenvasen des Reichen Stils und der Späten Klassik (Bonn: H. Bouvier und Co. Verlag)

Tsiafakis, D., 2003. 'ПЕ $\Lambda \Omega P A '$ Fabulous Creatues and/or Demons of Death?' in J. Michael Padgett ed., The Centaur's Smile: The Human Animal in Early Greek Art (Princeton: Princeton University Press) 73-104

Ure, A.D., 1962, 'Four lekythoi in Chalcis', in Journal of Hellenic Studies 82, 138-40

Ure, P.N., 1913. Black glaze pottery from Rhitsona in Boeotia (Oxford: Oxford University Press)

Vickers, M., 1999. Ancient Greek Pottery (Oxford: Ashmolean Museum)

Weiss, C., 1996. 'Vasi a forma di scarpa di produzione attica, ionica e della Magna Grecia' in G. Rizza ed., Consiglio Nazionale delle Ricerche. Centro di Studio sull'Archeologia Greca I. Vasi Attici ed alter ceramiche coeve in Sicilia I (Catania) $155-69$ 
Woolley, C.L., 1938. 'The Excavations at Al Mina, Sueidia II' in Journal of Hellenic Studies 58, 133-70 